\title{
Investigation and Study on College Tennis Players Sports Injuries
}

\author{
Laixiang Liu \\ Weifang University of Science and Technology, ShanDong ShouGuang, 262700, China; \\ E-mail:wfliulx@163.com
}

Keywords: Tennis; Teaching training; Athletic injury; Preventive measure

\begin{abstract}
The main purpose of this paper is to study the common sports injury of tennis teaching and training. We conducted a survey analysis of the research object using the method of literature, questionnaire survey,interview, mathematical statistics and other research methods. The results show that the damage reason, common areas, and the characteristics of tennis. The experimental data were gathered and compared. At the end of the paper, we study the tennis sports injury prevention measures, and summarize this study.
\end{abstract}

\section{Introduction}

Along with the economic prosperity and social progress, people in the pursuit of physical and mental health are becoming more and more highly. Tennis as a collection of leisure, fitness and so on the many kinds of value function as one of the sport, and as a kind of elegant and popular fitness activities, especially popular with the masses of teachers and students in colleges and universities and obsession. With the continuous popularization of tennis, sports injury has become play tennis enthusiasts technology level and improve a disorder. Therefore, a thorough investigation of tennis sports injury situation, analysis the common position, type, degree of injury and the reasons, on this basis, formulate scientific and targeted prevention measures, can be said to be the tennis is more popular and development problem to be solved.

\section{The research object and methods}

The research object . Social system of the students and the public physical education in a university tennis professional students and enthusiasts. 400 randomly selected tennis practitioners. 224 people including 224 boys and girls, duration of more than one year, and tennis in tennis practice $3 \sim 4$ times a week of tennis enthusiasts.

Methods: The literature material law, the questionnaire survey method, interview method, mathematical statistics method

\section{The results of the survey and analysis}

The basic characteristics of sports injuries of tennis. Tennis practitioner research content mainly includes: 1) whether in the process of playing tennis sports injuries happened;2) injury and type; 3) the cause of damage. Surveyed 355 exercisers, due to the damage occurred in the process of tennis practice of 231 people, accounting for $65.0 \%$ of the total. Among them 128 men, accounting for 
$55.4 \%$ of the damage; women, 103 people, accounting for $44.6 \%$ of the damage. Survey results show that the basic characteristics of the tennis game injury have the following several aspects:

1)the site of injury have close relationship with tennis technical movement master degree;

2)caused by partial burden of chronic injury, acute injuries, less injury, less serious damage;

3) tennis sports injuries with the tennis venue, equipment and supplies has a direct relationship, and general practitioners to sit with little tennis sports knowledge;

4)less normal teaching training injuries, while in some other teaching training practitioners damage;

5)the vast majority of practitioners do not understand tennis sports injury prevention measures.

Table 1 "tennis" sports injury causes

\begin{tabular}{|c|c|c|c|c|c|c|c|c|c|}
\hline $\begin{array}{l}\text { Injury and } \\
\text { reason }\end{array}$ & wrist & shoul der & elbow & les & ankle & knee & back & Comb ined. & $\%$ \\
\hline $\begin{array}{l}\text { Not wells } \\
\text { prepared }\end{array}$ & 2 & 16 & 12 & דים & 7 & 12 & דه & 37 & 30. 1 \\
\hline $\begin{array}{l}\text { Poor quality } \\
\text { of body and } \\
\text { mind }\end{array}$ & $-\infty$ & 15 & 5 & דـ & 5 & 3 & 1 & 28 & 22.8 \\
\hline $\begin{array}{l}\text { Local heavy } \\
\text { burden }\end{array}$ & 5 & 16 & 9 & 1 & 13 & 6 & 1 & 51 & 41.5 \\
\hline $\begin{array}{l}\text { Equipment is } \\
\text { not standard }\end{array}$ & 3 & $-\infty$ & - & - & 2 & 2 & $-\infty$ & 7 & 5.7 \\
\hline A combined & 10 & 47 & 26 & 1 & 27 & 23 & 2 & דه & דa \\
\hline percentage & 8. 1 & 38.2 & 21,1 & 1 & 22 & 18.7 & 1 & os & כדי- \\
\hline
\end{tabular}

Part of the tennis sport injury and classification . The results of the survey showed. Due to large tennis exercise intensity and exercise, so the occurrence of sports injury is also more common. This survey found in the part of the tennis sports

Injury is generally concentrated, parts are mainly involved in the seven (i.e., back, shoulder, elbow, wrist, leg, knee, ankle). The wrist joint damage up to 215 people, accounting for $60.5 \%$ of the total number of injuries, the rest of the injury is, in turn, elbow, shoulder and ankle. Damage types mainly include joint sprains, muscle strain, bruises, strain and periostitis, including joint sprains up to 226 people, accounting for $63.6 \%$ of the total damage, muscle strain, internal lesion caused by overexertion and periostitis.

Table 2

\begin{tabular}{|c|c|c|c|c|c|c|c|c|c|}
\hline $\begin{array}{l}\text { Injury and } \\
\text { reason }\end{array}$ & wrist & shoulder & elbow & leg & ankle & knee & back & Comb ined.. & $\%$ \\
\hline $\begin{array}{l}\text { Not wellw } \\
\text { prepared }\end{array}$ & 2 & 16 & 12 & $-\infty$ & 7 & 12 & $-\infty$ & 37 & 30.1 \\
\hline $\begin{array}{l}\text { Poor quality } \\
\text { of body and } \\
\text { minds }\end{array}$ & $-\infty$ & 15 & 5 & $-\infty$ & 5 & 3 & 1 & 28 & 22.8 \\
\hline $\begin{array}{l}\text { Local heavy } \\
\text { burden? }\end{array}$ & 5 & 16 & 9 & 1 & 13 & 6 & 1 & 51 & 41.5 \\
\hline $\begin{array}{l}\text { Equipment is } \\
\text { not standard }\end{array}$ & 3 & בגד & حهـ- & בד - & 2 & 2 & כד- & 7 & 5. 7 \\
\hline A combined & 10 & 47 & 26 & 1 & 27 & 23 & 2 & - & $-\infty$ \\
\hline $\begin{array}{l}\text { percentage } \\
\% \propto\end{array}$ & 8. 1 & 38.2 & 21.1 & 1 & 22 & 18.7 & 1 & $-\infty$ & כهـ \\
\hline
\end{tabular}




\section{Tennis sports injury causes}

In investigating the causes of injury in tennis are various, mainly have inadequate preparation, physical and mental quality is poor, the local burden, location equipment not standard and so on. See table 1.

In the process of investigating our tennis enthusiasts, I learned the professional tennis players and general tennis enthusiasts injured area and the reasons are different, I summarized by means of questionnaire survey table 2, table 3:

TABLE 3 TENNIS AMATEUR INJURY REASON

\begin{tabular}{|c|c|c|c|c|c|c|c|c|c|}
\hline $\begin{array}{l}\text { Injury and } \\
\text { reason }\end{array}$ & wrist & shoulder & elbow & leg & ankle & knee & back & Comb ined & $\%$ \\
\hline $\begin{array}{l}\text { Not well } \\
\text { prepared }\end{array}$ & 84 & 168 & حه & 18 & 145 & 4 & $-\infty$ & 570 & $\begin{array}{l}55 . \\
14\end{array}$ \\
\hline $\begin{array}{l}\text { Poor quality } \\
\text { of body and } \\
\text { mind }\end{array}$ & 21 & 39 & 2 & 5 & 16 & 2 & 10 & 86 & 8. 34 \\
\hline $\begin{array}{l}\text { Local heavy } \\
\text { burden }\end{array}$ & 7 & 80 & 5 & 5 & 43 & 6 & 8 & 154 & $\begin{array}{c}14 . \\
9\end{array}$ \\
\hline $\begin{array}{l}\text { Equipment is } \\
\text { not standard }\end{array}$ & 61 & -4 & 78 & 9 & 49 & 21 & 60 & 224 & $\begin{array}{l}21 . \\
7\end{array}$ \\
\hline A comb ined & 173 & 287 & 236 & 37 & 253 & 33 & 15 & - & $-\infty$ \\
\hline percentage & 16. 7 & 27.8 & 22.8 & 3.6 & 24.5 & 3. 2 & 1.5 & דهי- & דهי- \\
\hline
\end{tabular}

From table 2 and table 3 the analysis we can see that tennis majors because of long-term tennis movement, but also for tennis movement is likely to lead to injury in understanding, so the types of injury of tennis professional students appear largely because movement caused by too much. The tennis enthusiasts in the tennis sport in general is not very strong ego to protect consciousness, the frequency of the new sports injury is higher, and because the action error or action does not reach the designated position caused by the shoulder, elbow, wrist joints, such as more damage.

\section{Tennis sports injury prevention measures}

Technology to master the correct specification. Tennis is a great action sports technical requirements higher. Practitioners in both teaching and, therefore, in training, should be under the guidance of teachers (coaches), focusing on the specification of tennis movement, with the right technology practice as the core, and strictly according to the principle of step by step to master basic skills of tennis.

Be well prepared. Preparation activities are indispensable part of the practice. Its aim is to: when the body before getting into vigorous exercise, on the psychological and physiological make full preparation, make body and mind in a state of the activities of the best.

\section{Reasonable arrangement of sports load}

Improve physical and mental exercise. Tennis requires practitioners have strong physical quality level. Because the physical quality including strength, stamina, agility, speed, flexibility, etc., 
it is prone to injury of the muscle group in the muscles, joints, ligaments and the important role of protection.

To strengthen the medical supervision. Medical supervision is indispensable constituent, in the process of sports teachers and coaches in the tennis training in teaching process, first of all should fully know the causes of sports injury and prevent damage to the significance of teaching training mission and to the practitioner and the matters needing attention. In teaching techniques correctly and reasonably arrange exercise load at the same time, it should be pointed to teach knowledge to prevent the movement injury, prevent muscle soreness, eliminate fatigue, relax muscles, slow practitioners overburdened with local body relaxation exercise, to prevent the occurrence of sports injury.

\section{Conclusion}

Through the analysis of the research on the results of the survey show that tennis sports injury is given priority to with joint sprains, more and more attention in the wrist, elbow, shoulder and ankle parts of the body, and damage the main reason is that the technology to motion error and local burden. , therefore, to strengthen the specification of practitioners basics in teaching, pay attention to the strength and flexibility of training injury, avoid local muscle burden, to prevent the occurrence of sports injury plays an important role. In addition, tennis technique teaching and training, should be with "the standardization of the technical movements, the correct technique as the core, based on the comprehensive physical quality" to improve practitioners of tennis technique level.

\section{References}

[1] Li-xia Luan, Xiangfeng Xu. The investigation of the college tennis sports injury [J]. Journal of wuhan sports college journal, 2006, 33 (6) 6, 92-95

[2] Xirang Yang. Practical exercise physiology [M]. Beijing: Beijing Sport University Press, 1998.

[3] sports colleges general textbook. Sports medicine [M]. Beijing: People's game publishing house, 1990.

[4] Jiayun Hong. Try to talk about "tennis elbow" of the causes, diagnosis, prevention and treatment [J]. Journal of zhejiang sports science, 2004, 23 (1): 55 to 57.

[5] Xiaoyao Ke. Tennis court ten kinds of common diseases [j]. Journal of the tennis world, 2000 (8) : 62-63.

[6] WeiDong Bai. Study on treatment of "tennis elbow" [J]. Journal of sport science and technology, 2001, $22(4): 43-45$.

[7] Yinhui Wang. China's adolescent tennis athletes sport injury research. 2009, 29 of science and technology information

[8] Dong-shan Wang. Tennis teaching investigation and analysis of sports injury in training. On May 28, 2009 (3). Hubei sports technology

[9] Guojie Li. Student common sports injury prevention and treatment. 2010 (3). The life and the disaster

[10] Wei Chen. Sports professional students in sports injury research. 2 o10. 7. Sports academic world 
[11] Lixia Luan, Xiangfeng Xu. The investigation of the college tennis sports injury. June 2005 Wuhan Sports College journals 